\title{
The Politics of Immigration
}

\author{
Michael Bernhard and Daniel O'Neill
}

\section{After the Carnage}

n 2016, Donald J. Trump was elected President of the United States after a primary season in which he declared that "Lyin' Ted" Cruz had fraudulently stolen the Republican caucus in Iowa, and a general election contest in which he declared that he would only accept the results if he won. He claimed this was because his opponent could only be victorious if Democrats rigged the American electoral process against him. After losing to Hillary Clinton by roughly three million popular votes but winning the electoral college in what he deemed a "landslide," Trump offered up an inaugural address promising to deliver the nation from "American carnage." Immediately thereafter, his first press secretary, Sean Spicer, took the podium to assert in unequivocal fashion against all evidence that the forty-fifth president's swearing in ceremony was attended by the largest crowd ever seen at an inauguration. This was no "mistake," but part of an emerging pattern. Such breathtaking mendacity was in fact of a piece with that of his boss, who had earlier declared on Twitter (November 27) after the election: "In addition to winning the Electoral College in a landslide, I won the popular vote if you deduct the millions of people who voted illegally." Before Trump even took the helm, the tone was thus set for a chief executive who would go on to make more than 30,000 false or misleading statements during his time in office. ${ }^{1}$ Trump never accepted his popular vote loss in 2016 , and later attempted to substantiate his first version of the Big Lie by establishing a voting integrity commission, led by Kris Kobach, which was disbanded in 2018 because of its inability to find evidence of widespread voter fraud.

And what of Trump's promise to end American carnage? On his watch, by the most conservative estimates, some 400,000 Americans perished in a pandemic that was not managed well. Despite being considered by some as the country best prepared to respond to a pandemic (Cameron et al. 2019), the United States has the eighth highest COVID death rate per capita, and the largest total number of cases and deaths. ${ }^{2}$ Despite having less than $5 \%$ of the global population, the United States has roughly one-quarter of the world's total cases and one-fifth of its total deaths. The reasons for this are complex, but the president's denial of the crisis, mixed messaging on how to prevent transmission, lack of faith in science and willingness to publicly entertain quack remedies, calls to "liberate" states taking lockdown measures, and unwillingness to use the full capacity of the federal government to respond to the crisis are important parts of the failure (Hotez 2021). COVID deaths now exceed U.S. fatalities in any war in which we have participated except for our own Civil War, a figure that the United States may eventually surpass before all is said and done. During his time in office, Trump also presided over the most widespread and intense racial unrest since the 1960s; an explosion of public debt exacerbated by massive tax cuts during an economic boom, followed by one of the greatest economic downturns since the Great Depression; the loss of American power and prestige on the world stage unlike anything we have seen in the post-1945 era; climate change denialism; and the forfeiture of claims to moral leadership in the wake of immigration policies of extraordinary cruelty, which included separating families at the U.S. border, many of whose children have still not been reunited with their parents.

In the face of these facts, and despite the extraordinary advantages of incumbency, Trump lost his 2020 re-election bid to Joseph R. Biden, Jr. by the same electoral college "landslide" he had won with in 2016. Biden received over eighty-one million votes, seven million more than Trump, and the most ever garnered by any presidential candidate in American history. Like his three predecessors, Trump had entered office under unified government, with the Republicans controlling the House and Senate as well. His highly divisive style of governing had already brought that to an end in the midterm elections of 2018. Clinton, Bush, and Obama also lost unified government early in their terms, and only Bush was able to recover it, due to the "rally around the flag" effect of 9/11 (Shafer and Wagner 2019). Not only did Trump lose the House in 2018 and squander his own reelection in 2020, his efforts to delegitimize Biden's election led to the loss of two Senate seats in Georgia, flipping control of that body to the Democrats. He thus handed Biden, despite Democratic losses in the House, a unified government. This made him the first president since Herbert Hoover to lose the House, Senate and presidency for his party in one 
term, and it peacefully (if loudly) ushered Donald Trump out of office (but maybe not Trumpism).

Or at least so it seemed prior to the events of January 6,2021 . On that date, Donald Trump made good on his oft-repeated 2016 vow not to accept the results of an election he lost, by urging a huge crowd of his most fervent supporters to march on the Capitol with the aim of pressuring Congress and his own vice-president to invalidate the duly certified electoral college votes of several swing states through a process his personal attorney, Rudolph Giuliani, referred to as "trial by combat." The mob broke into the House of Representatives and the Senate, ransacking offices and desks, looting, defacing monuments, and calling for the vice president to be hung and the Speaker of the House to be shot. Numerous people were killed and injured. The violent insurrection was an ironic coda for the Trump presidency, which began on the Capitol steps with a promise to end American carnage, only to have his followers pillage the building in a fashion unseen since the British tried to burn it to the ground during the War of 1812 .

The question of the institutional toll that the Trump presidency has taken on American democracy remains open. On the one hand, in the aftermath of the insurrection Trump became the first American president ever to be impeached twice. On the other hand, before the insurrection 126 Republican members of the House of Representatives signed amicus briefs in support of a Texas lawsuit seeking to overturn the election results in four states (none of which was Texas). This was after an election which the Trump administration's own leading experts called the most secure in American history, and after dozens and dozens of lawsuits were tossed out of court for lack of evidence, lack of merit, or sheer frivolousness. Nevertheless, after the election well over one hundred Republican members of the House and more than a handful of Senators objected to the certified electoral votes of Arizona and/or Pennsylvania, thereby challenging the legitimacy of the election and of American democracy itself, even following the insurrectionary violence aimed at the sitting United States government. At the impeachment trial seven Republican senators voted with Democrats, but with the assistance of forty-three senators the ex-president escaped conviction a second time.

It is unclear how much carnage has been wrought in the last four years. What remains true, however, is that the pressing domestic and global problems mentioned have yet to be solved. Whether one of the world's oldest democracies is up to the scale of the challenges which face it seems less certain to us than at any time since the Civil War, and in the meantime the casualties of all sorts keep climbing.

\section{The Politics of Immigration}

In this issue, our special section focuses on immigration, one of the most salient concerns in the wake of the Trump era. One way of looking at the issues of identity posed by the politics immigration is through the lens of political culture. And from an intersubjective point of view, our culture is constituted through a series of points of mutual contention and agreement (Laitin 1988, 589). In most societies, identity is such a point of contention, and subject to periodic remaking. This is a multifaceted issue in the United States, where despite minimalist standards of democracy, not all subjects have enjoyed the full benefits of citizenship. And one of the most contentious points in this regard is over the role that immigration plays in American identity. In his recent prize-winning book, Michael Hanchard (2018) pinpoints discrimination against immigrants as one of the fundamental ways in which racial inequality continues to haunt Western democracy and the ability of political science to make sense of our own fundamental problems.

In the twentieth and twenty-first centuries, the United States has periodically paid homage to the notion that we are a nation of immigrants. It is important to remember that this has hardly been the rule. For example, Benjamin Franklin was highly concerned that the number of Germans settling in Pennsylvania would lead to the Germanification of the colony rather than the Anglicization of the newcomers. And for anyone doubting the social construction of whiteness in this society, it is worthwhile to recall that Franklin was the author of this tidbit: "And in Europe, the Spaniards, Italians, French, Russians and Swedes, are generally of what we call a swarthy Complexion; as are the Germans also, the Saxons only excepted, who with the English, make the principal Body of White People on the Face of the Earth" (Franklin 1751).

Our progress toward a more inclusive notion of "American" has been rocky. The Know-Nothing movement and associated political parties rose in strength during the increase in Catholic, largely Irish and German, immigration to this country in the mid-nineteenth century (Anbinder 1992). The need for cheap labor in the West due to construction of railroads led to a series of anti-Chinese laws including the Anti-Coolie Act (1862), the Page Act (1885), and the Chinese Exclusion Act (1882), which put draconian limits on Chinese immigration to this country (Hsu 2015), and the emergence of the Second Klan in America was also in response to the influx of Southern and Eastern Europeans, who were also seen as a threat to the native system of racial supremacy (MacLean 1995). That wave of immigration coincided with the rise of scientific racism and eugenic theory that dehumanized such immigrants and provided fodder for even worse forms of dehumanization later in the twentieth century (Barkan 1992). Even the progressives of the era saw things like school lunch programs as a way not only to feed poor children, but to wean immigrant children off the 
"unhealthy" food of their parents and socialize them into eating like Americans (Levine 2010, 5-6).

The Trump administration represented a major pendulum swing from the idea of America as "unique among nations ... [because] we draw our people-our strength-from every country and every corner of the world. And by doing so we continuously renew and enrich our nation." 3 The brutality of separating parents from children at the border, diverting funding from military families to build a symbolic but useless border wall, gutting protections for those seeking asylum from bloody dictatorships, and the rhetoric of "They're bringing drugs. They're bringing crime. They're rapists ..." 4 and "sh*thole countries" marked Trumpism as the very negation of Emma Lazarus's New Colossus. This reached the apex of insanity when the president himself mused over why we could not attract more Norwegian immigrants, who he undoubtedly thought would be itching to leave their wealthy homeland with its comprehensive welfare state for Trump's America, and the contention of Ken Cuccinelli, the acting director of U.S. Citizenship and Immigration Services, that Emma Lazarus "was referring back to people coming from Europe, where they had class-based societies, where people were considered wretched if they weren't in the right class." ${ }^{\text {It }}$ boggles the mind to recall that Trump thought of trying to trade Puerto Rico for Greenland.

In this issue we have brought together a series of articles that highlight the contemporary politics of immigration in some of its many forms. The geographic scope is broader than the United States, including other immigrant countries such as Canada and Australia, and includes two articles that take up the question in Europe. Since the 1960s, Europe has become more diverse as immigration increased due to decolonialization and the need for additional labor in expanding West European industry. With the rise of the European Union, the continent has assumed an even larger role as home for refugees and those seeking asylum. With these changes, Europe has had to confront issues of social integration and anti-foreign sentiment, including the rise of substantial parties with xenophobic agendas. The European Refugee crisis of 2015 was a major milestone in this regard, intensifying support for right-populist political forces and propelling the Brexit campaign in the United Kingdom, in part, to victory.

The first article, "How Interior Immigration Enforcement Affects Trust in Law Enforcement," by Tom K. Wong, S. Deborah Kang, Carolina Valdivia, Josefina Espino, Michelle Gonzalez, and Elia Peralta, is set in Trump's America. They examine how the treatment of undocumented immigrants by U.S. Immigration and Customs Enforcement (ICE) affects how undocumented immigrants relate to local law enforcement. Using survey experiment techniques, they find that cooperation between ICE and local law enforcement reduces trust in the latter. Thus, cooperation has the effect of reducing the effectiveness of law enforcement and reducing the safety of undocumented immigrant communities.

The next article is Patti Tamara Lenard and Terry Macdonald's piece, "Democracy versus Security as Standards of Political Legitimacy: The Case of National Policy on Irregular Migrant Arrivals." Lenard and Macdonald develop a novel normative framework for assessing the extent to which policies that curtail democratic governance can be justified as politically legitimate and develop a policy-oriented "security test" for doing so. They apply this metric to a case study of national policy on irregular boat arrivals to Australia and Canada. Their goal is to develop a richer theoretical understanding of political legitimacy, and clearer principles for balancing its competing demands.

The first article on Europe, "Institutionalization of Ethnocultural Diversity and the Representation of European Muslims," coauthored by Şener Aktürk and Yury Katliarou, explores the variation in Muslim descriptive representation across Europe. To carry out the study they created an original data set that identifies Muslim members in the lower chambers of parliament in twenty-six European countries from 2007 to 2018. They argue that those states that pursue policies that reflect a notion of the polity as "a union of multiple ethnocultural groups" should provide opportunities for better representation of Muslim minorities. They provide support for this thesis through multivariate regression and congruence testing in case studies of Belgium, France, the Netherlands, and Bulgaria.

In our second article on Europe, Kristina Bakkær Simonsen examines the turnout gap in voting between members of the titular majority and the children of immigrants. In "Politics Feeds Back: The Minority/Majority Turnout Gap and Citizenship in Anti-Immigrant Times," Bakkær Simonsen argues that this has been overlooked in the literature to date. Using the literature on policy feedback, she looks at how policies that target immigrants lead to different notions of citizenship and status in interviews with seventy-one majority and minority young people in Denmark. The author considers how anti-immigrant messages lead to withdrawal from politics and cautions us not to interpret this as disempowering. On the contrary, it may well allow minority youth a way to escape prejudice and thus empower themselves.

Yalidy Matos takes up the puzzle of why there is widespread support for the "Dreamers" in the United States in "The 'American DREAM': Understanding White American Support for the DREAM Act and Punitive Immigration Policies." She tries to figure out why large numbers of non-Hispanic whites both support the DREAM act and simultaneously favor more punitive and restrictive immigration policies. She argues that racial resentment and egalitarian values work to promote both 
dispositions and that this is common among self-identified white Democrats, a group Matos argues deserves more study given its seemingly paradoxical combinations of attitudes.

In "Social Welfare Attitudes and Immigrants as a Target Population: Experimental Evidence," Jake Haselswerdt examines the widespread belief that social welfare programs benefit immigrants more than native-born Americans and how these beliefs shape attitudes on policy. Using a survey experiment, he finds that a prime suggesting that immigrants are an economic threat leads to the belief that welfare programs benefit immigrants. At the same time, a prime that suggests immigrants are a cultural or demographic threat has no significant effect. In this way Haselswerdt helps to explain how the attitudinal pathway behind this long observed correlation works.

\section{Other Content}

Beyond the special section, our first article is "White Protectionism in America." In this wide-ranging essay Rogers Smith and Desmond King investigate claims of Donald Trump's racism and his denial of it by evaluating his campaign rhetoric and his administration's policies. Smith and King show that Trump's campaign spoke of an idealized American past that has been replaced with a present where elites have victimized traditionalist white Christian Americans. They then demonstrate how the policies of the Trump administration have expanded protections for this population, tried to expand their relative numbers in the electorate, and reduced protections for non-white and non-Christian voters and citizens, arguing that this constitutes a form of "white protectionism."

Dan Hiaeshutter-Rice, Stuart N. Soroka, and Christopher Wlezien explore how limits on public information can affect the citizenry's ability to respond to the government in "Freedom of the Press and Public Responsiveness." They use novel cross-national measures on spending preferences with data on spending levels and press freedom to examine the role of mass media in facilitating public responsiveness. As they hypothesize, they find evidence that when the media is constrained it inhibits the ability of the citizenry to respond to policy change. The article highlights the centrality of media freedom to the successful functioning of representative democracy.

Petter Nesser and Henrik Gråtrud address the question of how vulnerable states can avoid getting dragged into the internal conflicts of neighboring states. In "When Conflicts Do Not Overspill: The Case of Jordan" they show how the Hashemite kingdom has avoided large problems with jihadist violence despite its ubiquity in both Iraq and Syria. They attribute this absence to a state policy of "calibrated repression" which entails the use of force against infiltration by overseas jihadists and local terror cells, while working to coopt other domestic jihadist elements. The article contributes to our understanding of how it may be possible to avoid violent spillover in regions in which internal war is widespread.

In "The Politics of Marriage Equality: Nonconfrontational Officeholders and Confrontational Interest Groups," Christopher Baylor looks at the role of organized groups and politicians in the struggle to pass a marriage equality law in Rhode Island. Despite Democratic Party control of the state government, the first attempt to pass such legislation in 2011 was thwarted by the efforts of Catholic groups. In the next legislative cycle national interest groups intervened and challenged opponents of marriage equality, and this countermobilization led to passage in the new legislature. The article highlights the critical role of interest groups in battles over policy change.

The impact of "The Militarization of Law Enforcement in Latin America" is the subject of the contribution by Gustavo Flores-Macías and Jessica Zarkin. While many observers have examined how the police have come to operate more like military forces in the current period, the authors look at how soldiers have come to displace civilian police forces in Latin America. The article documents this "constabularization" of the military and explores its political consequences. To start, the tendency leads to a blurring of lines of civilian and military authority where it is adopted. Further, they argue that constabularization has deleterious effects on the quality of democracy by harming citizen security and respect for human rights and undermining both police reform as well as the rule of law.

Justin Schon explores how civilian communities deal with the uncertainty of civil war in "How Narratives and Evidence Influence Rumor Belief in Conflict Zones: Evidence from Syria." In armed conflict zones, the difficulty in attaining accurate and verifiable information means the difference between life and death. Because the stakes are so high, this promotes an environment where rumors, information that is intrinsically hard to verify, flourish. How then do people evaluate and make sense of such information, especially when elites may plant false information that is conducive to the attainment of their ends? Using a motivated reasoning framework, Schon argues that civilians rely on a combination of selfevaluation, evaluation of the source, and a process of collective sense-making to evaluate how accurate rumors are. He evaluates the framework on the basis of two hundred interviews with Syrian refugees in Jordan and Turkey which underlines the difficulty of verifying rumors, and also finds the ability of populations to evaluate rumors constrains the content that elite propaganda can take.

Finally, the issue concludes with a reflection essay, Alfred Moore's "Three Models of Democratic Expertise." 
Moore asks how expertise can best be integrated within democratic systems, and how such systems can best enable lay judgment of expert claims. He argues that the usual way for framing this question as a dichotomy between democratic politics against a pure "epistocracy" is misguided. Instead, he distinguishes three ways of democratically organizing relations between experts and nonexperts: representative expertise, participatory expertise, and associative expertise. Comparing these models, Moore explores how they can both support and undermine one another, and how they raise new questions about democracy, trust, and expertise for both political theorists and political scientists writ large.

\section{Notes}

1 This according to the Washington Post's "Fact Checker" as of January 24, 2021. Retrieved January 31, 2021

(https://www.washingtonpost.com/polit ics/2021/01/24/trumps-false-or-misleading-claimstotal-30573-over-four-years/).

2 Compiled by the commercial data firm Statista. Retrieved January 18, 2021 (https://www.statista.com/ statistics/1104709/coronavirus-deaths-worldwide-permillion-inhabitants/), based on Johns Hopkin's COVID-19 dashboard (https://coronavirus.jhu.edu/ map.html). Such statistics are limited by the data capacities of the state so it would be safer to say that the United States has the eighth worst record among countries with robust statistical services.

3 "Ronald Reagan's 'Remarks at the Presentation Ceremony for the Presidential Medal of Freedom' (January 19, 1989)." Retrieved January 25, 2021 (https://www. reaganlibrary.gov/archives/speech/remarks-presentationceremony-presidential-medal-freedom-5).

4 “Here's Donald Trump's Presidential Announcement Speech.” Retrieved January 25, 2021 (https://time. com/3923128/donald-trump-announcement-speech/).

5 "Trump Official: Statue of Liberty's Poem Is about Europeans.” Retrieved, January 25, 2021 (https:// apnews.com/article/290fe000b4584ddca46a6e b36a74a703).

\section{References}

Anbinder, Tyler. 1992. Nativism and Slavery: The Northern Know Nothings and the Politics of the 1850s. New York: Oxford University Press.

Barkan, Elazar. 1992. The Retreat of Scientific Racism: Changing Concepts of Race in Britain and the United States between the World Wars. New York: Cambridge University Press.

Cameron, Elizabeth E., Jennifer B. Nuzzo, Jessica A. Bell, et al. 2019. "Global Health Security Index, Building Collective Action and Accountability." Retrieved January 21, 2021 (https://www.ghsindex.org/wpcontent/uploads/2020/04/2019-Global-HealthSecurity-Index.pdf).

Franklin, Benjamin. 1751. "Observations Concerning the Increase of Mankind." National Archives, Founders Online. Retrieved January 21, 2021 (https:// founders.archives.gov/documents/Franklin/01-04-020080\#BNFN-01-04-02-0080-fn-0003).

Hanchard, Michael. 2018. The Spectre of Race: How Discrimination Haunts Western Democracy. Princeton, NJ: Princeton University Press.

Hotez, Peter J. 2021. “Anti-Science Kills: From Soviet Embrace of Pseudoscience to Accelerated Attacks on US Biomedicine.” PLOS Biology 19(1): e3001068. Retrieved January 31, 2021 (https://doi.org/10.1371/ journal.pbio.3001068).

Hsu, Madeline Y. 2015. The Good Immigrants: How the Yellow Peril Became the Model Minority. Princeton, NJ: Princeton University Press

Laitin, David. 1988. "Language Games." Comparative Politics 20(3): 289-302.

Levine, Susan. 2010. School Lunch Politics: The Surprising History of America's Favorite Welfare Program. Princeton, NJ: Princeton University Press.

MacLean, Nancy. 1995. Behind the Mask of Chivalry: The Making of the Second Ku Klux Klan. Oxford University Press.

Shafer, Bryon, and Regina Wagner. 2019. "The Trump Presidency and the Structure of Modern American Politics." Perspectives on Politics 17(2): 340-57. 


\section{Statement of Mission and Procedures}

Perspectives on Politics seeks to provide a space for broad and synthetic discussion within the political science profession and between the profession and the broader scholarly and reading publics. Such discussion necessarily draws on and contributes to the scholarship published in the more specialized journals that dominate our discipline. At the same time, Perspectives seeks to promote a complementary form of broad public discussion and synergistic understanding within the profession that isessential toadvancing scholarship and promoting academic community.

Perspectives seeks to nurture a political science public sphere, publicizing important scholarly topics, ideas, and innovations, linking scholarly authors and readers, and promoting broad reflexive discussion among political scientists about the work that we do and why this work matters.

Perspectives publishes work in a number of formats that mirror the ways that political scientists actually write:

Research articles: As a top-tier journal of political science, Perspectives accepts scholarly research article submissions and publishes the very best submissions that make it through our double-blind system of peer review and revision. The only thing that differentiates Perspectives research articles from other peer-reviewed articles at top journals is that we focus our attention only on work that in some way bridges subfield and methodological divides, and tries to address a broad readership of political scientists about matters of consequence. This typically means that the excellent articles we publish have been extensively revised in sustained dialogue with the editors to address not simply questions of scholarship but questions of intellectual breadth and readability.

"Reflections" are more reflexive, provocative, or programmatic essays that address important political science questions in interesting ways but are not necessarily as systematic and focused as research articles. These essays often originate as research article submissions, though sometimes they derive from proposals developed in consultation with the editor in chief. Unlike research articles, these essays are not evaluated according to a strict, doubleblind peer review process. But they are typically vetted informally with editorial board members or other colleagues, and they are always subjected to critical assessment and careful line-editing by the editor and editorial staff.

Scholarly symposia, critical book dialogues, book review essays, and conventional book reviews are developed and commissioned by the Associate and Book Review Editor, based on authorial queries and ideas, editorial board suggestions, and staff conversations.

Everything published in Perspectives is carefully vetted and edited. Given our distinctive mission, we work hard to use our range of formats to organize interesting conversations about important issues and events, and to call attention to certain broad themes beyond our profession's normal subfield categories.

For further details on writing formats and submission guidelines, see our website at http://www.apsanet.org/ perspectives/ 